\title{
Wildlife-livestock interface, veterinary cordon fence damage, lack of protection zones, livestock theft and owner apathy: Complex socio-ecological dynamics in Foot and Mouth disease control in southern Africa
}

\author{
Kabo Mogotsi ${ }^{1^{*}}$, Olaotswe Ernest Kgosikoma² and Keotshepile Fredric Lubinda ${ }^{3}$
}

\begin{abstract}
Current efforts to control and possibly eradicate the highly contagious and economically important Foot and Mouth disease (FMD) in Botswana are hampered by numerous inextricably linked constraints. These constraints were unveiled using a questionnaire-based approach among 94 communal area livestock owners in eastern Botswana's Zone 6 (FMD-free zone without vaccination, straddling part of the Central and North East Districts, sharing a common border with Zimbabwe to the east). The area has a history of FMD, with the last outbreaks recorded in 2002 and 2003 prior to the study. Some of the most outstanding constraints in FMD control were (1) rampant cross-border livestock theft, (2) veterinary cordon fence damage attributed to illegal immigrants and an ever-increasing elephant population, (3) livestock interaction with FMD-susceptible wild ungulates on the same rangelands, and (4) an absence of a protection zone (formerly 'buffer zone') along the Botswana/Zimbabwean border as well as (5) general apathy towards daily livestock management demonstrated by some owners/herders. The paper further discusses these complex socioecological constraints as perceived by livestock owners and offers possible policy considerations including targeted FMD awareness campaigns, strengthening of FMD risk analysis capacity and synchronization of surveillance and control strategies among neighbouring countries as well as adoption of approaches such as compartmentalization and commodity-based trade to enable greater access of Botswana's beef to high-value international markets.
\end{abstract}

Keywords: Botswana, Commodity based trade, Foot and Mouth Disease (FMD), Livestock theft, Transboundary animal disease management, Veterinary cordon fence, Wildlife livestock interface

\section{Introduction}

Botswana is a cattle country and always has been. The beef sub-sector transcends many other sectors of the economy and contributes about $80 \%$ to the overall agricultural gross domestic product (GDP). Under the dominant communal extensive grazing system, livestock, particularly cattle, are more than just a tradable commodity - they are an integral part of the socio-cultural

\footnotetext{
*Correspondence: kbmogotsi@yahoo.com; kbmogotsi@gov.bw

'Animal Production and Range Research Division, Department of Agricultural Research, Ministry of Agriculture, P. O. Box 10275, Francistown, Botswana Full list of author information is available at the end of the article
}

landscape. However, Botswana's livestock sector, as with most other countries in sub-Saharan Africa, has experienced Foot and Mouth disease (FMD) outbreaks through the years - with official records dating as far back as the early 1930s (Walker 1934). The highly communicable disease affecting even-toed ungulates is caused by the FMD virus (FMDV), classified within the Aphthovirus genus as a member of the Picornaviridae family (Belsham 1993). It is listed as a notifiable disease by the World Organisation for Animal Health (Office International des Epizooties, OIE). Historically, Botswana had three regions where FMD outbreaks were likely to 
occur, namely the Ngamiland (now Zones 2a, 2b, 2c, 2d, 2e, 2f) and Chobe area (now Zone 1), the Boteti river area (now Zone 4a) and the Nata area (now Zone 3b) (Falconer 1972; Mokopasetso and Derah 2005) which are areas with concentrated African buffalo (Syncerus caffer) populations. The earliest recorded FMD case was in 1933 caused by a variant of FMDV type O (Walker 1934), and this has been the only outbreak caused by the type $\mathrm{O}$ serotype. From 1935 to 1947 , there is a dearth of knowledge though it is suspected that outbreaks could have been due to the Southern African Territories (SAT) serotypes (Baipoledi et al. 2004). Eight outbreaks of FMD were further observed during the periods 1948 to 1970 (Falconer 1972), 1977 to 1979 and 1980 - all caused by SAT viruses 1, 2 and 3 or their combinations. Then two decades lapsed without any new outbreaks until 2002 to 2003 (Vosloo et al. 2002; Baipoledi et al. 2004).

Of late, however, outbreaks of FMD have been on the increase from 2006 to 2008, 2011 to 2012, to 2014 to 2015 (OIE 2015), even though some of these were in non-European Union (EU) export zones in northern Botswana. In order to realize accruable benefits derived from successful FMD control, Botswana together with other neighbouring states such as Namibia and South Africa has managed to secure OIE-certified FMD-free zones protected by a vaccination zone surrounding highrisk areas. Systems of elaborate networks of veterinary fences (approximately 10,000 km) and quarantine camps as well as disease-surveillance programmes coupled with compulsory and free vaccination campaigns have been put in place throughout the country for decades (Letshwenyo et al. 2004). This has largely facilitated access to regional and international beef markets like South Africa and as far as the EU and Norway. These achievements, supported by a strong legal framework, have been anchored on the Diseases of Animals Act (1977) and other subsidiary legislation such as Movement of Stock (restriction) Order as well as Quarantine and Compensation regulations. Other pertinent legislation includes the Control of Livestock Industry Act as well as the Livestock and Meat Industries Act.

Despite these commendable efforts which have largely contained the disease (Baipoledi et al. 2004; Mokopasetso and Derah 2005), the occasional outbreak of the transboundary FMD as well as the resultant economic cost and social disruption calls for a rethink in Botswana's approach. Research efforts have been directed more at the technical and less on the economical (e.g. Oarabile 1994; Kolanye and Mullins 2000) and social aspects of FMD outbreaks in Botswana, despite the recognized importance of community participation in veterinary service delivery in Africa (Catley and Leyland 2001). While estimates show that about $80 \%$ of Botswana's beef exports are from communal grazing areas, unfortunately, communal livestock farmers with different production objectives are often seen and treated passively - only to be involved in FMDvaccination campaigns and during the actual outbreak to contain and curb the spread of the disease. How local livestock farmers themselves perceive FMD, how it affects their enterprises and how they cope and adapt during and after outbreaks has received little attention in research circles, despite the great socio-economic importance of livestock to Batswana (citizenry of Botswana).

Perceptions or the range of judgments, beliefs and attitudes (Taylor et al. 1988) of respondents, priorities and human behaviour in general can be an important factor to consider, especially in disease dissemination and should be integrated in disease control planning (Chilonda and Van Huylenbroeck 2001; Scoones et al. 2010; Maree et al. 2014). Other studies have indicated that pastoralists do possess detailed knowledge about their livestock health problems (Rufael et al. 2008; Gabalebatse et al. 2013), as well as understanding of the pathology, vectors and reservoirs linked to the occurrence of disease (Ameri et al. 2009). Hence, some researchers (e.g. Shiferaw et al. 2010) further propose that the combined use of participatory appraisal and conventional methods may be essential for an ultimate disease control strategy. Therefore, this study set out to establish the constraints in FMD control as perceived by the affected agro-pastoral communities in the semi-arid environment of Botswana. This approach is in line with the adopted FMD control strategy which advocates for stakeholder involvement. Only by appreciating agro-pastoralists' perspective can a better understanding of FMD prevalence and persistence be realized and, in the same breath, its control and possible eradication from livestock regions of Botswana and southern Africa.

\section{Study area}

The study covered agro-pastoral communities in four villages (Mathangwane $21^{\circ} 00^{\prime} \mathrm{S} 27^{\circ} 20^{\prime} \mathrm{E}$, Borolong $21^{\circ} 6^{\prime}$ $13^{\prime \prime} \mathrm{S} 27^{\circ} 20^{\prime} 10^{\prime \prime} \mathrm{E}$, Matsiloje $21^{\circ} 18^{\prime} 07^{\prime \prime} \mathrm{S} 27^{\circ} 53^{\prime} 01^{\prime \prime} \mathrm{E}$ and Matopi $21^{\circ} 29^{\prime} 03^{\prime \prime} \mathrm{S} 27^{\circ} 56^{\prime} 16^{\prime \prime} \mathrm{E}$ ) within veterinary Zone 6, an FMD-free zone without vaccination and a beef exporter to international markets (EU). The zone straddles both the Central and North East Administrative Districts of Botswana. Significantly, the zone shares a common border with Zimbabwe to the east. The zone further shares a common border with Zone $3 \mathrm{c}$ to the north and west (green zone OIE-recognized FMD-free zone without vaccination), Zone 8 to large parts in the south (green zone OIE-recognized FMD-free zone without vaccination) and Zone 7 also in the south (OIE-recognized FMD-free zone with vaccination). Lines of cordon fences separate these zones. The zone, like the rest of the country, is relatively flat and semi-arid, with low and increasingly variable rainfall averaging about $470 \mathrm{~mm}$ annually. Major ephemeral rivers are Tati, Shashe, Ntshe and Ramokgwebana. 
The long-term maximum temperatures during winter (June to August) and summer (September to May) are approximately $23{ }^{\circ} \mathrm{C}$ and $35{ }^{\circ} \mathrm{C}$, respectively, with minimums down to approximately $4{ }^{\circ} \mathrm{C}$ during winter nights. The area is dominated by Colophospermum mopane woody species, with other vegetation associations including species like Acacia tortilis, Acacia nigrescens and Combretum apiculatum. Also present are grass species like Panicum maximum, Urochloa mosambicensis, Aristida congesta, Eragrostis rigidior and Schmidtia pappophoroides (Monametsi et al. 2012; Madzonga and Mogotsi 2014; Dambe et al. 2015). Sparsely populated clovenhoofed wild animals include the greater kudu (Tragelaphus strepsiceros), impala (Aepyceros melampus) and warthog (Phacochoerus africanus).

The area is characterized by the traditional livestock system (cattle posts or meraka) with communal grazing areas and shared water points. But exclusive ranches are also notably present, particularly in the North East District, which also happens to be the second smallest district in the country, thus leaving limited land for common usage. Cattle, goat and sheep farming are widely practised in addition to poultry and, to a negligible extent, piggery. Also present is one of the Botswana Meat Commission's (BMC) abattoirs in Francistown, with the sole mandate for all imports and exports of livestock and livestock products (BMC Act of 1965).

\section{Methods}

\section{Sampling procedure}

The survey involved four villages in total, namely Mathangwane and Borolong (Central District) as well as Matsiloje and Matopi (North East District), which all fall under Zone 6. Selection of villages took into consideration several factors. First, Matsiloje and Matopi are in close proximity to the Botswana/Zimbabwe border; thus, unique transboundary disease dynamics could be explored. Furthermore, livestock farmers in the two villages could have had direct experience with previous FMD outbreaks in 2002 and 2003. For the villages of Mathangwane and Borolong, although some distance from the border (approximately 75 and approximately $65 \mathrm{~km}$, respectively) and of less exposure to transboundary pressures, the presence or absence of an outbreak even in seemingly distant localities affects the two villages to some extent as they also share common FMD status and control strategies as the rest of Zone 6 . Secondly, the willingness of livestock farmers to partake in the study was also considered with help from the Department of Veterinary Services and the Department of Animal Production extension agents (under the Ministry of Agriculture). For example, in the village of Matshelagabedi (near Matsiloje), attempts to administer questionnaires failed as some visibly agitated livestock farmers declined to be interviewed, as they had earlier been informed of an FMD outbreak ${ }^{1}$ in their area and the subsequent decision to cull their cattle to contain the disease. The last consideration was the ease of logistical arrangements which was also instrumental in selecting Zone 6.

Livestock farmers (owners only) were randomly selected, and a total of 94 respondents were interviewed using a semi-structured questionnaire, with 52 in Borolong and Mathangwane while 42 were from Matsiloje and Matopi. The interviews were done during periods of relatively less labour demand (September) associated with agricultural activities such as calving or vaccination periods. The questionnaires were administered in the Setswana language by a team of enumerators, who had familiarized themselves with the questionnaire prior to the actual field survey. The questionnaire covered socioeconomic profiles of respondents as well as the perceived constraints encountered in the control and/or eradication of FMD in their area. The chi-square test $(x 2)$ was used to test for significant differences in constraints identified in the study areas, at $p<0.05$.

\section{Results \\ Socio-economic profile}

Table 1 shows the characteristics of heads of households in the study area, where the majority were elderly males. Only a small proportion of respondents had tertiary education. In addition to cattle, surveyed households also kept fewer other livestock species while main sources of income varied among households.

\section{Perceived constraints in FMD control}

Constraints identified by livestock farmers are reflected in Figure 1. A myriad of constraints ranged from the prevailing land tenure system (e.g. communal land use and inadequate grazing land), through institutional capacity factors (e.g. lack of research, inadequate field veterinarians and ineffective vaccination strategy), to local-level risk factors (e.g. apathy, stray livestock and fence damage). Overall, as many as 20 possible constraints were mentioned by livestock owners, with 13 being common to both study areas. Fence damage $(p=0.002)$ and non-vaccination in neighbouring Zimbabwe $(p=0.005)$ were significantly different between the border villages (Matsiloje/Matopi) and the more inland villages (Borolong/Mathangwane), while vaccine inefficiency was just marginally non-significant $(p=0.056)$.

The most outstanding constraints in FMD control and possible eradication were livestock theft (62.2\%), veterinary cordon fence damage $(36.8 \%)$, lack of protection zones $(27.3 \%)$, wild animals (24.2\%) and general apathy among the surveyed communities (19.1\%). 
Table 1 Characteristics of households in the study area (Zone 6), Botswana

\begin{tabular}{|c|c|c|}
\hline Variable & Matsiloje + Matopi $(n=42) \%$ & Borolong + Mathangwane $(n=52) \%$ \\
\hline \multicolumn{3}{|l|}{ Gender (head of household) } \\
\hline (a) male (b) female & (a) 59.5 (b) 40.5 & (a) 69.2 (b) 30.8 \\
\hline \multicolumn{3}{|l|}{ Age (head of household) } \\
\hline$\leq 35$ years & 7.1 & 5.8 \\
\hline 36 to 50 years & 14.3 & 13.5 \\
\hline 51 to 60 years & 9.5 & 28.9 \\
\hline$>60$ years & 69.1 & 51.9 \\
\hline \multicolumn{3}{|l|}{ Education (head of household) } \\
\hline None & 40.5 & 25.0 \\
\hline Primary & 38.1 & 44.2 \\
\hline Secondary & 16.7 & 21.2 \\
\hline Tertiary & 4.8 & 9.6 \\
\hline \multicolumn{3}{|l|}{ Main income source } \\
\hline Crop sales & 11.9 & 19.2 \\
\hline Stock sales & 71.4 & 55.8 \\
\hline Informal employment & 0.0 & 7.7 \\
\hline Government Old Age Pension Scheme & 9.5 & 11.5 \\
\hline Full-time employment & 2.4 & 3.8 \\
\hline Government Food Baskets & 2.4 & 0.0 \\
\hline Other & 2.4 & 1.9 \\
\hline \multicolumn{3}{|l|}{ Livestock owned } \\
\hline (a) cattle (b) goats (c) sheep (d) donkeys (e) other & (a) 100 (b) 85.7 (c) 26.2 (d) 23.8 (e) 7.1 & (a) 100 (b) 75 (c) 11.5 (d) 4.9 (e) 17.3 \\
\hline
\end{tabular}

\section{Discussion}

\section{Perceived constraints in FMD control}

The five most mentioned constraints are further expounded on next, and the intricate linkages between them are highlighted.

\section{Veterinary cordon fence damage}

The use of cordon fences that separate livestock from areas inhabited by susceptible wild animals and livestock to control the transmission of infectious diseases is a common strategy in Botswana and southern Africa in general, recognized by the OIE for establishing diseasefree zones in beef-exporting countries (Thomson 1999). The adoption of this strategy is also based on the premise that airborne virus transmission remains remote in sub-Saharan Africa (Thomson 1994; Mokopasetso 2005). Thus, near the villages of Matsiloje and Matopi, a double-line cordon fence with a defoliated $10 \mathrm{~m}$ in between (varies with terrain) runs just along the ephemeral Ramokgwebana river which separates Botswana and Zimbabwe. The cordon fence, first erected in the late 1970s, runs for approximately $235 \mathrm{~km}$ from Dikgatlhong northwards up to Vakaranga, with staffed pickets at every 2.5 to $3 \mathrm{~km}$ along the fence. The international border line itself is unfenced, and previous attempts to erect an electrified fence by Botswana were considered controversial and were subsequently shelved.

Most reported acts of damage were along the eastern side of the zone along the border with Zimbabwe. Damage observed along the fence was caused in part by illegal movements of people across the border at ungazetted points. In addition to general damage by illegal immigrants, the cordon fence was also cut by criminals who moved/smuggled goods, particularly livestock, across the two countries. Also accompanying these criminal activities is the likelihood of transmitting FMD through clovenhoofed animal-derived products such as fresh milk and meat as well as other disease-carrying fomites which could have been detected, confiscated and disposed or dipped/ decontaminated had official check points been used as dictated by movement protocols. At times, particularly during the dry season, livestock may be drawn towards the standing grass biomass in between the double fence lines or the water sources (hand-dug wells on the dry sandy Ramokgwebana river bed) on the other side of the fence. This, however understated, means an increase in 


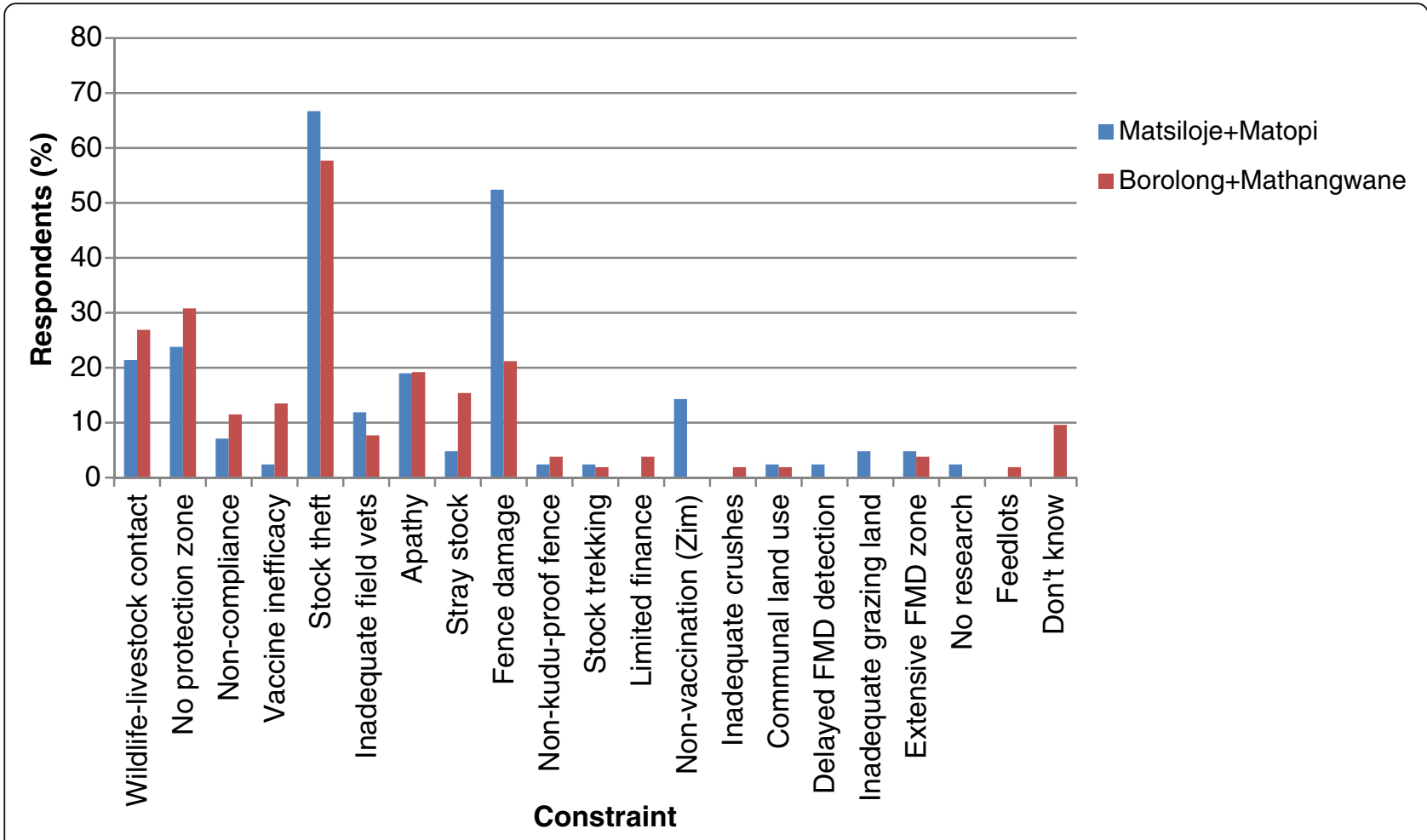

Fig. 1 Constraints identified in the control of foot and mouth disease in the study area

livestock density lurking in very close proximity to the cordon fence in order to seize any opportunity to access feed and water.

Elephants (Loxodonta africana) were also a major contributing factor to the observed fence damage (further expounded below under section on wild animals). Jori et al. (2011) also identified elephants and anthropogenic activities as the two most important causes of damage to the veterinary cordon fence separating wildlife and livestock along the boundary of the Kruger National Park in South Africa. Even in settings where cordon fences are electrified like in South Africa, stealing of batteries and solar panels may render the fence ineffective (Jori et al. 2009). All these frequent damages to the cordon fence in the study area not only put a strain on the dwindling resources mobilized for fence maintenance but also expose agro-pastoral communities to concurrent multiple stressors such as livestock going astray into Zimbabwe and increased human-wildlife conflicts. In contrast, veterinary cordon fences in other areas of Botswana like Chobe and Ngamiland are further compromised by annual veld fires as well as flooding. While proving effective, gameproof fencing comes at a financial cost (construction, maintenance and patrol) which may prove prohibitive in some countries (Sutmoller 2002; Sinkala et al. 2014) and continue to meet mounting resistance from conservationists due to its detrimental ecological effects (Mbaiwa and Mbaiwa 2006; Gadd 2012). Research on the impact of veterinary cordon fencing in northern Botswana also demonstrated restricted patterns of resource access and pastoral mobility resulting in negative implications for social and environmental sustainability (McGahey 2008; 2011).

As with the rest of the country, veterinary cordon fences remain the property of the State and are legally protected from damage/vandalism due to anthropogenic activities (accidental or not) and penalties exist under the Diseases of Animals Act.

\section{Wild animals}

Southern African rangelands support both livestock and a rich diversity of wildlife, with the latter also central to national economies and conservation efforts. One wild animal often mentioned in the same line with FMD outbreaks in livestock in the region is the African buffalo, though restricted to wildlife areas in Botswana. This is because African buffalo (one of the 'big five' and a tourist attraction) are a known natural reservoir for SAT-type FMDV in southern Africa (Condy and Hedger 1974; Mapitse 1998), which makes control of FMDV not only challenging but its eradication untenable in the near future. The role of other wild cloven-hoofed animals apart from the African buffalo in virus maintenance and transmission of FMD has been extensively researched in southern Africa (e.g. Anderson et al. 1993; Letshwenyo et al. 2006; Vosloo et al. 2009; Weaver et al. 2013). Thus, the presence of wild ungulates in the study area such as the 
greater kudu (T. strepsiceros) and impala (A. melampus), which are known intermediary transmitters of FMDV, makes outbreaks likely. This is even more so due to an increased elephant population (an Appendix I CITES species and one of the 'big five', approximately 200,000 in Botswana) which damages the non-electrified cordon fence, thus enabling smaller ungulates including possibly infected livestock to cross undeterred.

The frequency of fence damage caused by elephants has increased partly due to the largest newly constructed Dikgatlhong dam (just below the confluence of the Shashe and Tati rivers with capacity of 400 million $\mathrm{m}^{3}$ ) on the Botswana side not far from the border. This dam draws animals especially during the dry seasons when the ephemeral Ramokgwebana river dries up, thereby also increasing the likelihood of direct contact between FMD-susceptible wild animals and livestock. In light of increased frequency and intensity of droughts expected under a changing climate in southern Africa, such increased direct contacts between domestic and wild animals could be expected as more and more animals congregate around fewer water points and shrinking grazing lands (for animals with similar ecological niches). Though no systematic records exist, most elephant damage reported was observed between Dikgatlhong dam and Matsiloje village, ${ }^{2}$ which is not entirely surprising as this forms part of the elephants' home ranges between water points and grazing areas. In South Africa, Jori et al. (2009) also highlighted elephant-related fence breaks as a factor in FMD outbreaks in areas adjacent to the Kruger National Park, especially during the dry winter months (June and July) and in February/March when elephants are attracted by Sclerocarya birrea (morula) fruits outside the fence perimeter.

An interesting point to note is the current height of the double cordon fence. The inner fence on the western side (Botswana) is stock proof at $1.4 \mathrm{~m}$ high, while the one on the eastern side (Zimbabwe) is stock and game proof at $2.4 \mathrm{~m}$. However, in areas like Matopi, both fences are at a height of $1.4 \mathrm{~m}$ (presumably for ease of maintenance following relentless pressure by elephants). In an earlier study by Hargreaves et al. (2004) in Zimbabwe on the outbreak of FMD in cattle adjacent to a conservancy, epidemiological investigations showed that it was most likely that antelope (impala or kudu) infected through contact with the buffalo herd within the conservancy had jumped over the fence and transmitted the virus to nearby cattle herds. Following this incident, the height of fencing surrounding conservancies in Zimbabwe was increased to a minimum of $2.3 \mathrm{~m}$ (Hargreaves et al. 2004), which may prompt reconsideration on the sufficiency of the current cordon fence height. In fact, a small number of respondents in the current study did mention the non-kudu-proof fence as a possible constraint in combating the disease.

\section{Livestock theft}

Livestock theft, particularly of cattle, was highlighted as a constraint in the fight against FMD in the study area by over half of all respondents. According to the Government of Botswana (2011), livestock theft in Botswana has generally been on the rise in the recent past, thus prompting establishment of an Anti-Stock Theft Unit within the Police Service in order to curb this crime, coupled with other pertinent legislation such as the Stock Theft Act (1996). While livestock theft has been observed as a challenge to livestock producers in other parts of the country (Mosalagae and Mogotsi 2013) and in other countries in the region such as Lesotho (Kynoch and Ulicki 2000), Malawi (Malekano 2000), Swaziland (Simelane 2005), South Africa (Kunene and Fossey 2006), Zimbabwe (Mavedzenge et al. 2008) and Namibia (Olbrich et al. 2012), it is even more complex in areas bordering other countries since it involves increased exposure to risks such as economically devastating transboundary diseases like FMD.

The modus operandi, which is also aided by the vastness of Zone 6, involves stealing of livestock (particularly cattle, small stock and, to the bemusement of Batswana, donkeys) from either country along the cordon fence by criminal syndicates or individuals, driving them further away from their usual grazing and watering points (cattle posts) and exchanging them with another stolen batch of livestock from the neighbouring country. Or instead of exchanging live animals, one could be sold stolen livestock, knowingly or not. In some instances, stolen livestock from Botswana could be herded illegally into Zimbabwe where they are further moved from the area of entry and later driven back into Botswana at a different locality where they are then reared or sold. Some local butcheries and unscrupulous individuals may provide the market for such stolen livestock, contrary to the legal process of inspection of animals before slaughter (Livestock and Meat Industries Act of 1962). This is further exacerbated by failure to brand and ear mark livestock as expected of livestock owners (Branding of Cattle Act). Because of the criminality of these movements, the cordon fence is almost always cut to facilitate cross-border movement or fence sections damaged by elephants used as crossing points. And if there are any FMD-infected livestock or fomites involved, so will the subsequent spread of the disease.

Furthermore, since the adjacent Zimbabwean region is considered an area with unknown disease status, any stray livestock that do attempt to return to Botswana (originating/belonging to Botswana owners that cross into Zimbabwe) are immediately destroyed and owners compensated as per the existing policy (Diseases of Animals Act (1977) - Determination of the Value of Compensation Order) in order to control the disease and protect the rest of the zone. Yet, stray livestock originating from 
Zimbabwe that manage to cross into Botswana are promptly driven back to Zimbabwe - a possible policy gap in disease control which could also breed negligence among Zimbabwean herd owners and resentment among Botswana farmers for perceived double standards by authorities. $^{3}$ That notwithstanding, communal livestock owners still decry the low compensation rates (BWP400 and BWP25 per animal for cattle and sheep/goats, respectively, where USD1 $=$ BWP10.88 as at July 7, 2016). There is the socio-economic importance of their livestock and the public good they undertake by being the first line of defence in implementing FMD control measures for the benefit of the whole country.

This compensation factor should never be overlooked, and the right incentives ought to be put in place as individual livestock owners may, for example, surreptitiously reassemble any of their stray and/or stolen livestock from Zimbabwe and be less inclined to report. This scenario would inevitably increase exposure to FMD risk for the whole region. On the other hand, caution should be exercised lest compensation amounts become high enough (above market prices) to act as some sort of inducement or incentive for allowing animals (willingly or not) to illegally cross into Zimbabwe just to claim monetary compensation. This so-called moral hazard should be considered in the design of compensation schemes, to avoid scenarios where individual livestock producers take less care over biosecurity risks because the scheme offers sufficient compensation in case of outbreaks and loss (OECD 2011; OECD 2012). Thus, there is need to delicately strike a balance or alternatively offer replacement of livestock in lieu of monetary compensation. Brückner et al. (2002) also noted the difficulty in convincing South African communal farmers who mainly keep livestock for socio-economic reasons why their apparently healthy animals must be culled during FMD control. And the post-culling experience can be quite traumatic for individuals involved even in intensive enterprises, as was the case with the 2001 United Kingdom and the Netherlands FMD outbreaks (Cuijpers and Osinga 2002; Van Haaften et al. 2004; Mort et al. 2005) as well as the 2010 outbreak in Japan (Hibi et al. 2015).

It is worth noting that livestock theft alone can have devastating impacts not only on individual households (e.g. through loss of draught power) but also on agrarian communities at large since their entire livestock asset base (some of high-value genetic material) which took years of effort to accumulate can be lost overnight - leaving them increasingly vulnerable to poverty, while cross-border relations could also be strained in the process.

\section{Lack of protection zone ${ }^{4}$}

As earlier described, the study area has an international border on its eastern side with neighbouring Zimbabwe, along the ephemeral Ramokgwebana river that acts as a natural physical barrier. There is only the non-electrified double-line cordon fence on the Botswana side separating the two countries. Since previous FMD outbreaks in the area have been traced back to Zimbabwe (e.g. Baipoledi et al. 2004; Mokopasetso and Derah 2005), livestock farmers felt the need to have a protection zone along the border to act as a first line of defence. The major challenge with the transboundary transmission of FMD as noted by Sinkala et al. (2014) is that surveillance systems are not always synchronized between countries, or during outbreaks and control strategies are not carried out simultaneously, thus spillovers are inevitable. While Borolong/Mathangwane (the more inland villages) as well as Matopi/Matsiloje (near-border villages) cited the lack of a protection zone as a constraint, a higher percentage of respondents sharing this view were in the former study area. Two deductions arise. First, there is a strong call for 'protection' from FMD incursions originating from outside Botswana's borders by livestock owners in general. And secondly, the inland villages of Borolong/Mathangwane 'know' that advocating for a protection zone along the border line, and being further away from the border, would likely render them more 'secure' and FMD free. Protection zones have been used successfully in the southern African region in the control of transmission of FMDV from FMD-vaccination zones. However, this is not always possible under the conditions that prevail in southern Africa (Thomson and Bastos 1994), where land availability has dramatically decreased and where there is a growing necessity to integrate and rationalize land use (Hargreaves et al. 2004). This is especially true in the North East District, where land is already limited.

The establishment of a protection zone could be of economic importance as the main EU-bound beef exporter, the BMC abattoir, is situated less than $50 \mathrm{~km}$ away in Francistown. This abattoir (which is already operating below full capacity), should it be shut down due to outbreaks in the study areas, will also adversely affect other neighbouring livestock areas (FMD free) such as parts of the Central District which also sell to the same BMC abattoir. FMD outbreaks resulting in subsequent movement restrictions, ban on beef exports and possible stamping out also contribute to unintended but unfortunate unemployment (e.g. of hired herders and managers) and reduced businesses in livestock transportation, animal feed and associated sectors. The other factor to consider is the importance of the Ramokgwebana river to the community particularly in providing water for their livestock. A protection zone which precludes farmers from accessing this vital resource without providing alternatives will receive less support and could undermine disease control efforts in the future. 


\section{Apathy}

Lack of interest in daily management particularly among some livestock owners was cited as a challenge in combating FMD in the study areas. Such absentee farmers, often termed 'remote control farmers', may reside either in villages or towns, away from their livestock at the cattle posts, and rarely check on the welfare of both their livestock and hired herders (Mosalagae and Mogotsi 2013). The latter would also, upon realizing the neglect shown by their employers, either be de-motivated to continue tending to the animals (mostly watering, herding and general routine management) or worse abandon the animals. This in turn has ripple effects such as debilitated and poorly maintained livestock enclosures, animals not being kraaled in enclosures at night, animals going astray and some stolen as a consequence by opportunistic livestock thieves or organized criminal syndicates - sometimes with herders being implicated in such crimes.

In recent years, livestock herding is considered a menial job (with low remuneration rates and lack of tangible benefits) by the youth and less people are willing to do it, leaving the less energetic elderly to look after their own livestock. The youth would rather move to nearby villages and Francistown where they are engaged in equally or more paying temporary jobs under non-agricultural sectors like construction and mining. As a result, livestock owners often resort to hiring immigrants, some of whom may have entered the country illegally. This puts livestock owners at risk of having their livestock abandoned during patrols by law enforcement agencies (with herders arrested, fined and deported while stock owners are also fined for employing and harbouring illegal immigrants) or the herders stealing their employers' livestock and crossing the border. Also closely related to this scenario is the implied non-compliance with existing FMD biosecurity measures which was mentioned by some respondents.

The perception of apathy demonstrated by owners and herders alike could also arise from the subsistence nature of extensive livestock farming in Botswana, which may not necessarily require intensive herd management. It is a low-input, low-output system. A similar observation has been made by McGahey (2011) in Botswana's Ngamiland, where there was positive attitude among some livestock owners and herders towards veterinary cordon fences particularly in curbing stock theft and preventing cattle from straying as far as Namibia. People are aware that their livestock cannot go beyond the cordon fences (barring permeability due to wildlife and anthropogenic damage), and so, they let their stock graze freely within the area without close herding or no herding at all. This is even more so during dry seasons when water sources become key focal points where livestock congregate, thereby reducing herding labour demand as well as time to round up the animals. Even in instances where animals do go astray, herders and owners will search for them within the confines of the cordon fences first, before raising an alarm. And since the last FMD outbreaks in the study area were recorded in 2002 and 2003, it is natural for people in general to let their guard down once a perceived threat has passed.

This complacency could ultimately lead to risky practices and behaviour patterns among some agro-pastoral households, resulting in another FMD outbreak. While highly commending Botswana's advanced zoning system, findings of a 2010 evaluation report on veterinary services in Botswana based on the OIE-PVS (Performance of Veterinary Services) method also stated that 'maintaining such extensive zoning measures for long time periods is challenging because people become less vigilant and the general public finds the control measures burdensome' (OIE 2016). While also contemplating reasons for the increased frequency of FMD outbreaks and increased duration to resolve such outbreaks in the Southern African Development Community (SADC) region, Barnes (2013) also suggested that livestock owners may have become less observant of animal health regulations than in the past. Brückner et al. (2002) further caution against the danger of complacency arising among veterinary staff who do not perceive FMD as a real threat, which could create problems when mobilizing personnel in the event of an outbreak (which requires rapid and effective response).

\section{Policy considerations}

Some of the constraints identified by livestock owners like livestock theft, cordon fence damage, stray livestock and apathy can be countered to some extent with aggressive awareness campaigns, stakeholder and community involvement (e.g. engaging Farmer Associations). Strong emphasis must always be placed first and foremost on how successful FMD control and eradication benefits livestock owners, both large and small-scale, rather than the government. This will inculcate trust, a sense of ownership, vigilance and compliance which are all pivotal in disease control.

On the technical side, it should always be noted that there is no single FMD eradication strategy that is perfect or even appropriate for all circumstances, and thus, epidemiological factors, livestock husbandry systems, stakeholder lobbying, community acceptance, likely cost and other public health policies (e.g. health and environmental) interacting with animal health policy (FAO 2002; OECD 2012) should be considered. Technical innovation based on Botswana's unique context is thus needed. The identified challenge in FMD control due to the absence of a protection zone along the Botswana/ Zimbabwe border, despite previous outbreaks being traced back to that country, is a prime example. This could also signal the need to strengthen FMD risk 
analysis capacity (risk identification, assessment, mitigation or management and communication).

With regard to the presence of FMD-susceptible wild ungulates on the same grazing lands used by livestock as well as damage of cordon fences by elephants, the situation is even more complex. Nature-based tourism, for which southern Africa has a comparative advantage, is an important revenue earner for Botswana, only second to minerals which are finite resources under an extractive industry. So both livestock and tourism sectors are integral in efforts to safeguard and develop rural livelihoods and therefore should sustainably complement each other. A possible approach is the adoption of Botswana's renowned Community-Based Natural Resource Management (CBNRM) model by communities in the study area to achieve the twin objectives of nature conservation and economic empowerment of locals - with possible realignment (not total removal) of the cordon fence blocking elephant movement corridors and home ranges particularly access routes to Dikgatlhong dam. Land is already limited in this area, and stakeholders will have to be flexible, innovative and accommodative of integrated land use proposals. As an example, a percentage of revenue generated from ecotourism activities under such a model could be channelled back into fence fortification, patrol and maintenance. This then calls on different stakeholders within the livestock and conservation fields, who are often the biggest impediment to meaningful win-win dialogue, to find a middle ground that drives towards compatibility as advocated for by Niamir-Fuller et al. (2012) in East Africa.

The non-synchronization of surveillance systems and control strategies between neighbouring countries is an important weakness resulting in disease re-emergence. This was also revealed in the current study where livestock farmers perceived the non-vaccination in neighbouring Zimbabwe (Matebeleland South Province) as a constraint in the effective control and eradication of FMD in the region. This then calls for a more orchestrated effort by SADC states and a possible private investment by various interest groups like Beef and Dairy Farmers' Associations to augment limited government coffers in keeping farming areas disease free, as also advocated for by Scoones et al. (2010). This willingness to pay for FMD control by farmers remains largely unexplored. The Government of Botswana (2015) also identified the limited transboundary disease control collaboration with neighbouring Zimbabwe as a considerable risk factor for future FMD outbreaks. ${ }^{5}$ To support current government efforts, private veterinarians too should gradually be integrated into the country's animal health policy a transition which according to OECD (2012) may be aided by allowing private veterinarians to charge for some of the currently free services offered to livestock farmers (e.g. veterinary drugs and biologicals such as vaccines) except for official priority diseases as well as engaging private veterinarians in government-funded vaccination campaigns to augment public veterinarians. Current proposals to outsource some of the services under the Department of Veterinary Services are a welcome development in this regard (for example, patrol and maintenance of cordon fences as well as engagement of veterinary para-professionals under the 'Private Bakenti' initiative). However, caution should be exercised during outsourcing attempts to allow key components to be retained by the State to guard against possible deterioration of veterinary services leading to collapse of disease control systems.

While livestock owners, veterinarians and animal product industries undoubtedly have a role to play in the control and eradication of FMD, it is primarily up to the scientific community to take the lead. Unconventional approaches such as compartmentalization and commoditybased trade (CBT) integrated with the existing food safety risk management system Hazard Analysis Critical Control Points (HACCP) could enable greater access of beef to international markets. These approaches provide alternatives to the current geographically (zonation) based standards through mitigation of animal disease hazards potentially associated with specific commodities or products, irrespective of the disease status of the place of origin (Thomson et al. 2004; Thomson et al. 2009; Scoones et al. 2010; Rich and Perry 2011; Thomson et al. 2013; Letshwenyo 2015). Though the OIE has accepted the approaches (OIE 2012) as well as the SADC states through the Phakalane Declaration of 2012 (see https://www.wcs-ahead.org/phakalane_declaration.html), limited progress has been realized in terms of implementation. Lobby groups should continue to advocate for its implementation, while SADC could also play a major role in advancing its position at the OIE, and expand trade among member states using the CBT approach to gradually demonstrate to cautious markets the principle of equivalence.

\section{Conclusion}

Botswana has made great strides in the control of the highly contagious FMD over the years, mainly through systems of elaborate networks of veterinary fences, quarantine camps and compulsory and free vaccination campaigns supported by a strong legal framework. Recent incursions and outbreaks, however, threaten the sanitary status of the country and its high-value beef export market. The current study unveiled numerous barriers or constraints as perceived by communal livestock owners, who are key foot soldiers in the continuing battle against FMD. These constraints should be addressed through 
locally contextualized policy interventions with full engagement of all stakeholders, which will ultimately ensure the country's global competitiveness in livestock and related products, hence securing marginal rural agro-pastoral economies under a changing climate.

\section{Endnotes}

${ }^{1}$ The FMD outbreak which started in April 2011 caused by FMDV SAT was eradicated by stamping out all 47,578 cattle and 25,232 small ruminants in the containment zone within Zone 6. The zone has since been disease free and restocked by November 2013 (OIE, World Organisation for Animal Health 2015). Compensation policy for cattle: Option 1: $100 \%$ cash (owners of $\leq 10$ cattle), Option 2: $70 \%$ cash and $30 \%$ restocking - with BWP1700.00 per animal irrespective of the age, condition or breed of the animal, but dairy cows were later adjusted to BWP7500.00 per animal (approximately USD1 $=$ BWP10.88 as at July 7, 2016). Small-stock compensation policy: $100 \%$ restocking.

${ }^{2}$ In 2015, the use of ground chilli pepper, a non-lethal technique, on cordon fences to deter elephants was piloted around Matopi village by the Department of Veterinary Services, though no systematic evaluation has been carried out on its effectiveness.

${ }^{3}$ Botswana is currently considering implementing a policy to immediately destroy any cattle on sight from Zimbabwe that stray into Botswana.

${ }^{4}$ Since the study, Zone 6 has been demarcated into Zones $6 \mathrm{a}$ and $6 \mathrm{~b}$ by approximately $180 \mathrm{~km}$ of $2.4-\mathrm{m}$-high fence. The surveyed villages of Borolong and Mathangwane are under Zone 6a, while Matopi and Matsiloje now fall under Zone $6 \mathrm{~b}$ (protection zone) along the Botswana/Zimbabwe border. Zone $6 \mathrm{~b}$ forms part of a series of contiguous protection zones stretching across the country from east to west, essentially protecting FMD-free without-vaccination zones in the south from any FMDV incursions from FMD-infected zones in the north - with a strong resemblance to Namibia's (in)famous Veterinary Cordon Fence (VCF) or the 'Red Line'.

${ }^{5} \mathrm{~A}$ joint cattle-vaccination campaign along the border on the Zimbabwean side is ongoing with assistance from Botswana's Department of Veterinary Services.

\footnotetext{
Acknowledgements

The authors are grateful to G. Ntsimanyana, K. Galesekwe (Department of Agricultural Research, Mahalapye), M. Koobonye (Department of Agricultural Research, Impala), P. Gabotlale and B. Letsholo (Internship Programme attachés, Impala) for the field data collection. J. Makore (Biometry Unit, Department of Agricultural Research, Sebele) guided the questionnaire design process. Dr. K. Botlhole and L. Mogaetsho (Department of Veterinary Services, Francistown) and the extension officers (Department of Animal Production, Francistown) are acknowledged for their valuable insight and identification of farmers in the study area, respectively. Chiefs (Dikgosi) of the four surveyed villages and farmers involved are greatly acknowledged for their cooperation, time and willingness to be part of the study. All field
}

logistics were supported by the Department of Agricultural Research, Ministry of Agriculture. Valuable comments from reviewers also improved the manuscript.

\section{Authors' contributions}

KM conceived the research idea and study design, participated in the data collection and drafted the manuscript. OEK and KL commented on and improved the initial manuscript. All authors read and approved the final manuscript.

\section{Authors' information}

$\mathrm{KM}$ is a researcher in rangeland ecology and management particularly in semi-arid environments. OEK specializes in ecosystem management under semi-arid environments. $\mathrm{KL}$ is a veterinarian with emphasis on livestock disease control.

\section{Competing interests}

The authors declare that they have no competing interests.

\section{Author details}

${ }^{1}$ Animal Production and Range Research Division, Department of Agricultural Research, Ministry of Agriculture, P. O. Box 10275, Francistown, Botswana.

${ }^{2}$ Animal Production and Range Research Division, Department of Agricultural Research, Ministry of Agriculture, P/Bag 0033, Gaborone, Botswana. ${ }^{3}$ Disease Control Division, Department of Veterinary Services, Ministry of Agriculture, P. O. Box 19, Francistown, Botswana.

Received: 17 July 2016 Accepted: 24 September 2016

Published online: 26 October 2016

\section{References}

Ameri, A.A., Hendrickx, S., Jones, B., Mariner, J., Mehta, P. and Pissang, C. 2009. Introduction to participatory epidemiology and its application to highly pathogenic avian influenza participatory disease surveillance: A manual for participatory disease surveillance practitioners. ILRI, Nairobi, Kenya.

Anderson, E.C., C. Foggin, M. Atkinson, K.J. Sorensen, R.L. Madekurozva, and J. Nqindi. 1993. The role of wild animals, other than buffalo, in the current epidemiology of foot-and-mouth disease in Zimbabwe. Epidemiology and Infection 3: 559-563.

Baipoledi, E.K., G. Matlho, M. Letshwenyo, M. Chimbombi, E.K. Adom, M.V. Raborokgwe, and J.M. Hyera. 2004. Re-emergence of foot-and-mouth disease in Botswana. The Veterinary Journal 168: 93-99.

Barnes, J.I. 2013. Economic analysis of land use policies for livestock, wildlife and disease management in Caprivi, Namibia, with potential wider implications for regional transfrontier conservation areas. Technical report to the Wildlife Conservation Society's AHEAD Program and the World Wildlife Fund. 84

Belsham, G.J. 1993. Distinctive features of foot-and mouth disease virus, a member of the Picornavirus family; aspects of virus protein synthesis, protein processing and structure. Progress in Biophysics and Molecular Biology 60: $241-260$.

Brückner, G.K., W. Vosloo, B.J.A. Du Plessis, P.E.L.G. Kloeck, L. Connoway, M.D Ekron, D.B. Weaver, C.J. Dickason, F.J. Schreuder, T. Marais, and M.E. Mogajane. 2002. Foot and mouth disease: The experience of South Africa. Revue scientifique et technique-Office international des épizooties 21: 751-764.

Catley, A., and T. Leyland. 2001. Community participation and the delivery of veterinary services in Africa. Preventive Veterinary Medicine 49: 95-113.

Chilonda, P., and G. Van Huylenbroeck. 2001. A conceptual framework for the economic analysis of factors influencing decision-making of small-scale farmers in animal health management. Revue scientifique et technique-Office international des épizooties 20: 687-700.

Condy, J.B., and R.S. Hedger. 1974. The survival of foot and mouth disease virus in African buffalo with non-transference of infection to domestic cattle. Research in Veterinary Science 16: 182-185.

Cuijpers, M.P., and K.J. Osinga. 2002. The position of the Dutch Farmers' Union on lessons learned and future prevention and control of foot and mouth disease. Revue scientifique et technique-Office international des épizooties 21: 839-850.

Dambe, L.M., K. Mogotsi, M. Odubeng, and O.E. Kgosikoma. 2015. Nutritive value of some important indigenous livestock browse species in semi-arid mixed Mopane bushveld, Botswana. Livestock Research for Rural Development. 
Article \#209 27: 10. Retrieved January 18, 2016, from http://www.lrrd.org/ Irrd27/10/mogo27209.htm.

Falconer, J. 1972. The epizootiology and control of foot-and-mouth disease in Botswana. The Veterinary Record 91: 354-359.

FAO, Food and Agriculture Organization. 2002. Preparation of foot and mouth disease contingency plans. Rome: FAO Animal Health Manual No. 16.

Gabalebatse, M., B.N. Ngwenya, D. Teketay, and O.D. Kolawole. 2013. Ethnoveterinary practices amongst livestock farmers in Ngamiland District, Botswana. African Journal of Traditional, Complementary, and Alternative Medicines 10: 490-502.

Gadd, M.E. 2012. Barriers, the beef industry and unnatural selection: A review of the impact of veterinary fencing on mammals in Southern Africa. In Fencing for conservation, restriction of evolutionary potential or a riposte to threatening processes? Somers, M.J, ed. M. Hayward, 153-186. New York: Springer.

GoB, Government of Botswana. 2011. Crime prevention guidelines for livestock.. Gaborone. http://www.gov.bw/en/Ministries-Authorities/Ministries/ State-President/Botswana-Police-Service-/About-the-BPS/Stock-Theft-Branch/. Accessed 12 Jan 2013.

GoB, Government of Botswana. 2015. Foot and mouth disease contingency plan for Botswana. Gaborone: Ministry of Agriculture Revision 4.

Hargreaves, S.K., C.M. Foggin, E.C. Anderson, A.D.S. Bastos, G.R. Thomson, N.P. Ferris, and N.J. Knowles. 2004. An investigation into the source and spread of foot and mouth disease virus from a wild life conservancy in Zimbabwe. Revue scientifique et technique-Office international des épizooties 23: 783-790.

Hibi, J., A. Kurosawa, T. Watanabe, H. Kadowaki, M. Watari, and K. Makita. 2015. Post-traumatic stress disorder in participants of foot-and-mouth disease epidemic control in Miyazaki, Japan, in 2010. The Journal of Veterinary Medical Science 77: 953-959.

Jori, F., W. Vosloo, B. Du Plessis, R. Bengis, D. Brahmbhatt, B. Gummow, and G.R. Thomson. 2009. A qualitative risk assessment of factors contributing to foot and mouth disease outbreaks in cattle along the western boundary of the Kruger National Park. Revue scientifique et technique-Office international des épizooties 28: 917-931.

Jori, F., D. Brahmbhatt, G.T. Fosgate, P.N. Thompson, C. Budke, M.P. Ward, K. Ferguson, and B. Gummow. 2011. A questionnaire-based evaluation of the veterinary cordon fence separating wildlife and livestock along the boundary of the Kruger National Park, South Africa. Preventive Veterinary Medicine 100: 210-220.

Kolanye, M.G., and G.R. Mullins. 2000. The cost to the government of the control of foot and mouth disease in Botswana: A study conducted by the economics unit of the Veterinary Epidemiology and Economics Section, Department of Animal Health and Production. Gaborone: Ministry of Agriculture.

Kunene, N.W., and A. Fossey. 2006. A survey on livestock production in some traditional areas of northern Kwazulu Natal in South Africa. Livestock Research for Rural Development. 18, Article \#113 18: 30-33. Retrieved January 18, 2016 http://www.lrrd.org//rrd18/8/kune18113.htm.

Kynoch, G., and T. Ulicki. 2000. "It is like the time of Lifaqane": Impact of stock theft and violence in southern Lesotho. Journal of Contemporary African Studies 18: 179-206.

Letshwenyo, M. 2015. Maintaining foot and mouth disease-free status: The southern African experience (including vaccination and wildlife issues). In: Proceedings of the "FAO/OIE Global Conference on Foot and mouth Disease - Ensuring excellence and ethics of the veterinary profession" held 27-29 June 2012. Bangkok: FAO and OIE.

Letshwenyo, M., M. Fanikiso, and M. Chimbombi. 2004. The control of foot and mouth disease in Botswana: Special reference to vaccination. Developments in Biologicals 119: 403-413.

Letshwenyo, M., N. Mapitse, and J.M.K. Hyera. 2006. Foot and mouth disease in a kudu (Tragelaphus strepsiceros) in Botswana. The Veterinary Record 159: $252-253$.

Madzonga, Z., and K. Mogotsi. 2014. Production, harvest and conservation of Lablab purpureus (L) sweet forage in semi arid livestock regions: The case of east central Botswana. Journal of Animal and Plant Sciences 24: 1085-1090.

Malekano, L.B. 2000. Paper presented at the "International Conference on Historical and Social Science Research in Malawi" 26-29 June 2000. Malawi: University of. The socio-economic impact of stock-theft and disease in the Lower Shire District of Malawi, http://www.eldis.org/vfile/upload/1/document/1009/ Stock-theft\%20and\%20disease.doc. Accessed 15 Jan 2016.

Mapitse, N. 1998. The African buffalo (Syncerus caffer) is a reservoir of foot and mouth disease in Botswana. Masters Thesis. The Royal Veterinary College, University of London.
Maree, F.F., C.J. Kasanga, K.A. Scott, P.A. Opperman, M. Chitray, A.K. Sangula, R. Sallu, Y. Sinkala, P.N. Wambura, D.P. King, D.J. Paton, and M.M. Rweyemamu. 2014. Challenges and prospects for the control of foot-and-mouth disease: An African perspective. Veterinary Medicine: Research and Reports 5: 119-138.

Mavedzenge, B.Z., J. Mahenehene, F. Murimbarimba, I. Scoones, and W. Wolmer. 2008. The dynamics of real markets: Cattle in southern Zimbabwe following land reform. Development and Change 39: 613-639.

Mbaiwa, J.E., and O.I. Mbaiwa. 2006. The effects of veterinary fences on wildlife populations in Okavango Delta, Botswana. International Journal of Wilderness 12: $17-41$.

McGahey, D.J. 2008. Maintaining opportunism and mobility in drylands: The impact of veterinary cordon fences in Botswana. PhD thesis. University of Oxford.

McGahey, D.J. 2011. Livestock mobility and animal health policy in southern Africa: The impact of veterinary cordon fences on pastoralists. Pastoralism: Research, Policy and Practice 1: 14.

Mokopasetso, M. 2005. Modeling foot and mouth disease risk factors in Botswana. Tropicultura 23: 13-16.

Mokopasetso, M., and N. Derah. 2005. Recent outbreaks of foot and mouth disease in Botswana and Zimbabwe. Tropicultura 23: 8-12.

Monametsi, N.F., S.W. Makhabu, and K. Mogotsi. 2012. The effects of cattle-goat mixed grazing on steer performance and rangeland condition in semi-arid north eastern Botswana. Botswana Journal of Agriculture and Applied Sciences 8: 67-74.

Mort, M., I. Convery, J. Baxter, and C. Bailey. 2005. Psychosocial effects of the 2001 UK foot and mouth disease epidemic in a rural population: Qualitative diary based study. BMJ 331(7527): 1234.

Mosalagae, D., and K. Mogotsi. 2013. Caught in a sandstorm: An assessment of pressures on communal pastoral livelihoods in the Kalahari Desert of Botswana. Pastoralism: Research, Policy and Practice 3: 18

Niamir-Fuller, M., C. Kerven, R. Reid, and E. Milner-Gulland. 2012. Co-existence of wildlife and pastoralism on extensive rangelands: Competition or compatibility? Pastoralism: Research, Policy and Practice 2: 1.

Oarabile, L. 1994. The epidemiology and economics of foot and mouth disease control in Botswana. MSc dissertation: University of Reading.

OECD, Organisation for Economic Co-operation and Development. 2011. Managing risk in agriculture: Policy assessment and design. Paris: OECD.

OECD, Organisation for Economic Co-operation and Development. 2012. Livestock diseases: Prevention, control and compensation schemes. Paris: OECD Publishing. doi:10.1787/9789264178762-en.

OIE, World Organisation for Animal Health. 2012. Health standards: Commoditybased approach. http://www.oie.int/international-standard-setting/overview/ commodity-based-approach/. Accessed 10 Jan. 2016.

OIE, World Organisation for Animal Health. 2015. Status report on foot and mouth disease in Botswana. http://www.oie.int/wahis_2/public/wahid.php/ Reviewreport/Review/viewsummary?reportid=10548. Accessed 15 Jan 2016

OIE, World Organisation for Animal Health. 2016. OIE-PVS evaluation report on the veterinary services of Botswana (29th March - 9th April 2010). http:// www.oie.int/fileadmin/Home/eng/Support_to_OlE_Members/pdf/ FinalReport_Botswana.pdf. Accessed 4 Feb 2016.

Olbrich, R., M.F. Quaas, and S. Baumgärtner. 2012. Characterizing commercial cattle farms in Namibia: Risk, management and sustainability. University of Lüneburg Working Paper Series in Economics, No. 248. http://hdl.handle.net/ 10419/73177. Accessed 15 Jan 2015

Rich, K.M., and B.D. Perry. 2011. Whither commodity based trade? Development Policy Review 29: 331-357.

Rufael, T., A. Catley, A. Bogale, M. Sahle, and Y. Shiferaw. 2008. Foot and mouth disease in the Borana pastoral system, southern Ethiopia and implications for livelihoods and international trade. Tropical Animal Health and Production 40: 29-38.

Scoones, I., A. Bishi, N. Mapitse, R. Moerane, M.L. Penrith, R. Sibanda, G. Thomson, and W. Wolmer. 2010. Foot-and-mouth disease and market access: Challenges for the beef industry in southern Africa. Pastoralism: Research, Policy and Practice 1: 2.

Shiferaw, T.J., K. Moses, and K.E. Manyahilishal. 2010. Participatory appraisal of foot and mouth disease in the Afar pastoral area, northeast Ethiopia: Implications for understanding disease ecology and control strategy. Tropical Animal Health and Production 42: 193-201.

Simelane, H.S. 2005. Cross-border cattle rustling and its socio-economic impact on rural southern Swaziland, 1990-2004. Journal of Contemporary African Studies 23: 215-231. 
Sinkala, Y., M. Simuunza, D.U. Pfeiffer, H.M. Munang'andu, M. Mulumba, C.J. Kasanga, J.B. Muma, and A.S. Mweene. 2014. Challenges and economic implications in the control of foot and mouth disease in Sub-Saharan Africa: Lessons from the Zambian experience.. Veterinary Medicine International, http://dx.doi.org/10.1155/2014/373921.

Sutmoller, P. 2002. The fencing issue relative to the control of foot-and-mouth disease. Annals of the New York Academy of Sciences 969: 191-200.

Taylor, J.G., T.R. Steward, and M. Downton. 1988. Perceptions of drought in the Ogallala aquifer region. Environment and Behaviour 20: 150-175.

Thomson, G.R. 1994. Foot and mouth disease. In: Infectious diseases of livestock with special reference to southern Africa, ed. J.A.W. Coetzer, G.R. Thomson, and R.C. Tustin, 825-852. Southern Africa: Oxford University Press.

Thomson, G.R. 1999. Alternatives for controlling animal diseases resulting from interactions between livestock and wildlife in Southern Africa. South African Journal of Science 95: 71-76.

Thomson, G.R., and Bastos, A.D.S. 1994. Foot-and-mouth disease. In: Infectious diseases of livestock with special reference to southern Africa 2, Coetzer J.A.W., G.R. Thomson, and R.C. Tustin (Eds), 825-852. London: Oxford University Press.

Thomson, G.R., E.N. Tambi, S.K. Hargreaves, T.J. Leyland, A.P. Catley, G.G.M. van't Klooster, and M.L. Penrith. 2004. International trade in livestock and livestock products: The need for a commodity-based approach. The Veterinary Record 155: 429-433.

Thomson, G.R., T.J. Leyland, and A.I. Donaldson. 2009. Deboned beef - an example of a commodity for which specific standards could be developed to ensure an appropriate level of protection for international trade. Transboundary and Emerging Diseases 56: 9-17.

Thomson, G.R., M.L. Penrith, M.W. Atkinson, S. Thalwitzer, A. Mancuso, S.J. Atkinson, and S.A. Osofsky. 2013. International trade standards for commodities and products derived from animals: The need for a system that integrates food safety and animal disease risk management. Transboundary and Emerging Diseases 60: 507-515.

Van Haaften, E.H., M. Olff, and P.H. Kersten. 2004. The psychological impact of the foot and mouth disease crisis on Dutch dairy farmers. Njas-Wageningen Journal of Life Sciences 51: 339-349.

Vosloo, W., A.D.S. Bastos, O. Sangare, S.K. Hargreaves, and G.R. Thomson. 2002. Review of the status and control of foot and mouth disease in sub-Saharan Africa. Revue scientifique et technique-Office international des épizooties 21: 437-449.

Vosloo, W. P.N. Thompson, B. Botha, R.G. Bengis, and G.R. Thomson. 2009 Longitudinal study to investigate the role of impala (Aepyceros melampus) in foot-and-mouth disease maintenance in the Kruger National Park, South Africa. Transboundary and Emerging Diseases 56: 18-30.

Walker, J. 1934. Some observations of foot-and-mouth disease in the Bechuanaland Protectorate. Journal of the South African Veterinary Medical Association 5: 73-91.

Weaver, G.V., J. Domenech, A.R. Thiermann, and W.B. Karesh. 2013. Foot and mouth disease: A look from the wild side. Journal of Wildlife Diseases 49: 759-785.

\section{Submit your manuscript to a SpringerOpen ${ }^{\circ}$ journal and benefit from:}

- Convenient online submission

- Rigorous peer review

- Immediate publication on acceptance

- Open access: articles freely available online

- High visibility within the field

Retaining the copyright to your article 